\title{
Growth of Stock Market in the UAE through Merger: A Comparative Study of GCC Stock Markets
}

\author{
Robinson Joseph ${ }^{1} \&$ Manuel Fernandez ${ }^{1}$ \\ ${ }^{1}$ Skyline University College, Sharjah, UAE \\ Correspondence: Manuel Fernandez, Skyline University College, PO Box 1797, University City of Sharjah, Sharjah, \\ UAE. Tel: 971-6-5441-155. E-mail: qln_manuel@yahoo.com
}

Received: July 6, 2016

Accepted: July 21, 2016

Online Published: August 11, 2016

doi:10.5430/afr.v5n3p190

URL: http://dx.doi.org/10.5430/afr.v5n3p190

\begin{abstract}
In recent years, stock exchanges have increasingly been forming alliances or merging with each other. This study is carried out with the objective of finding out the benefits of having a larger single stock market in the UAE instead of the present two separate markets: Abu Dhabi Securities Exchange and Dubai Financial Market. The study covers a period of five years from 2010 to 2014. This study is based on secondary data collected from various stock exchanges in the GCC. The various stock markets in the GCC are compared against each other on the basis of volume and value of trading, market capitalization, number of shares listed and number of days traded. Then, a similar analysis is carried out with the combined ADX and DFM. It is observed that the merger of ADX and DFM brings in benefits on all these parameters. The study also shows that the merger will benefit all the stakeholders by reducing cost of operations facilitated by the large scale operations, sophisticated technology, single trading platform, one investor number, lower trading cost and earlier break-even. Moreover, through the merger the UAE will be able to attract more local and regional companies which will enhance the revenue, profitability and presence in the region.
\end{abstract}

Keywords: Merger, Stock Exchanges, Gulf Cooperation Council (GCC), Market Capitalization, Stock Trading

\section{Introduction}

A stock market is a public market for the trading of company stocks and derivatives at an agreed price. The size of the world stock market was estimated at about US\$64.19 trillion at the end of 2013 (WFE 2013). The revenue and profitability of the stock exchanges depend on its volume of business. The main sources of revenue for stock exchanges are: Listing revenues that accrue from stock market listing services; Trading revenues from trading in financial instruments; and Services revenues from post-trading activities, data dissemination and IT services. Analysis of revenue distribution of World Federation of Exchange (WFE) members over a five year period (2008-2012) reveals that large share of income is generated by trading services (Table 1). Lower revenues may induce the smaller exchanges to pursue some form of consolidations in future.

Table 1. World Federation of Exchanges (WFE) members: Total Revenue Breakdown (2008 to 2012)

\begin{tabular}{lrrrrr}
\hline Percentage of Revenue & 2008 & 2009 & 2010 & 2011 & 2012 \\
\hline Listing revenues & $6.20 \%$ & $6.30 \%$ & $6.30 \%$ & $6.40 \%$ & $6.30 \%$ \\
Trading revenues & $52.40 \%$ & $53.90 \%$ & $62.30 \%$ & $60.90 \%$ & $61.00 \%$ \\
Other Services revenues & $33.30 \%$ & $32.40 \%$ & $24.90 \%$ & $23.20 \%$ & $25.80 \%$ \\
Financial income & $4.00 \%$ & $2.90 \%$ & $2.90 \%$ & $6.50 \%$ & $4.90 \%$ \\
Others & $4.20 \%$ & $4.50 \%$ & $3.50 \%$ & $2.90 \%$ & $2.00 \%$ \\
\hline
\end{tabular}

Source: compiled from WEF, Cost and Revenue Survey 2008 to 2012.

\subsection{The GCC}

The Gulf Cooperation Council (GCC) is an oil-based region with the largest proven crude oil reserves in the world (486.8 billion barrels), representing 35.7\% of the world's total. The six countries of the GCC region, namely Bahrain, Kuwait, Oman, Qatar, Saudi Arabia and the United Arab Emirates, have enjoyed a spectacular economic boom until late 2008. The GCC economy tripled in size to \$ 1.1 trillion during 2002 to 2008 . For the GCC region, oil and gas sector represents approximately $73 \%$ of total export earnings and roughly $63 \%$ of government's revenues. The region 
is continuing its economic reform program, focusing to attract domestic, regional and foreign private sector investments into various sectors like oil and gas, power generation, telecommunications, and real-estates. But the recent downward slide in the oil price has slowed the pace of investment and development projects in the region's economic activities. The predications are that the oil price will continue to be low which will in the near future compel these economies to look for other sources of revenue for growth and development. Stock markets can play a vital role in attracting investors to these markets.

\subsection{GCC Stock Markets}

The year of setting up of the individual GCC stock market differs, but the early 1990s marked the real beginning of these markets (Table 2). Each country's effort to diversify its economy, privatize its public sectors, utilize modern sophisticated technology in stock trading, establish honest legal system and enhance financial institutional infrastructures brought about the real development of these markets in the 1990s. As a result, the GCC markets have managed to attract some foreign individual and institutional investors to redirect some investments to them (Hammoudeh \& Aleisa, 2004).

Table 2. The GCC Stock Markets

\begin{tabular}{llccc}
\hline Market & Country & \multicolumn{2}{c}{ Year of } & \multicolumn{2}{c}{ Shares listed, May 2015 } \\
& & Establishment & Number & Rank \\
\hline Abu Dhabi Securities Exchange (ADX) & U.A.E. & 2000 & 70 & 5 \\
Bahrain Bourse (BHB) & Bahrain & $1987 *$ & 46 & 6 \\
Qatar Stock Exchange (QSE) & Qatar & $1995 * *$ & 43 & 7 \\
Dubai Financial Market (DFM) & U.A.E. & 2000 & 71 & 4 \\
Kuwait Stock Exchange (KSE) & Kuwait & 1977 & 205 & 1 \\
Muscat Securities Market (MSM) & Oman & 1988 & 117 & 3 \\
Tadawul ( Saudi Stock Exchange) & Saudi Arabia & $1984 * * *$ & 170 & 2 \\
\hline
\end{tabular}

Sources: Compiled from ADX; BHB; QSE; DFM; KSE; MSM and Tadawul.

*Bahrain Bourse was established in 2010, which replaced the Bahrain Stock Exchange (BSE)

**Activities started in May 1997.

***The Tadawul platform was launched in 2001, but an organized stock market existed from 1984.

\subsection{United Arab Emirates}

The United Arab Emirates (UAE) is located in the middle of the Arabian Gulf. The UAE is a federation of seven Emirates including Abu Dhabi, Dubai, Sharjah, Ajman, Umm al-Quwain, Ras al-Khaimah and Fujairah, which are governed by the Federal Supreme Council (FSC) of rulers. Abu Dhabi and Dubai, the largest and the wealthiest two emirates, dominate the UAE economy. It is a rich and open economy with a high per capita income and a sizable annual trade surplus. Oil and Gas account for nearly $25 \%$ of GDP, $45 \%$ of export earnings and $40 \%$ of government revenue. Since the discovery of oil in the UAE, it achieved a profound transformation from a small desert region to a modern state with a very high standard of living ('www.gulfbase.com'). There are three stock exchanges in the UAE:

\section{Abu Dhabi Securities Exchange}

Abu Dhabi Securities Exchange (ADX) (formerly Abu Dhabi Securities Market, ADSM) is located in Abu Dhabi. It was established on 15 November 2000 to trade shares of UAE companies.

\section{Dubai Financial Market}

The Dubai Financial Market (DFM) is a stock exchange located in Dubai. The Market commenced operations on 26 March 2000.

\section{NASDAQ Dubai (formerly called the Dubai International Financial Exchange, DIFX)}

It is a stock exchange which opened on September 26, 2005 in Dubai. NASDAQ Dubai is an international stock exchange open to investors of any nationality based in any country. It has issuers based in countries all over including UK, South Africa, Australia, India, Kuwait, Bahrain, and Saudi Arabia ('www.nasdaqdubai.com').

The UAE is a small country with a population of about nine million and three stock exchanges, one in Abu Dhabi the capital city and two in Dubai the commercial hub. Considering the limited size and population, the existence of three 
stock exchanges may well limit each market in terms of liquidity, order flows from international institutional investors and new listing requests from local and regional firms. This situation is further complicated by the presence of more than one regulatory authority: ADX and DFM are regulated by Securities and Commodities Authority (SCA), while NASDAQ-Dubai is supervised by Dubai Financial Services Authority. The common goal of Abu Dhabi and Dubai, the two main emirates of the UAE, is to become the financial hub of the Persian Gulf, but both the states are following different strategies to reach this goal. In spite of all the efforts of both these stock markets their market capitalization and trading value are very low. This has provoked the idea of the merger of ADX and DFM with the intention to take advantage of the synergies of M\&A.

The basic objective of this study is to examine the synergies that can be achieved through the merger of ADX and DFM, the two major stock exchanges in the UAE.

This paper is organized as follows: the Section 2 presents a literature review on M\&A aspects in stock exchanges. The Section 3 states the methodology. The Section 4 focusses on analysis and discussions, and Section 5 concludes the paper.

\section{Literature Review}

A stock exchange is a regulated capital market in which equity and debt instruments are issued and traded in primary and secondary markets (Kokkoris \& Olivares-Caminal, 2007). In the past, mergers of stock exchanges were not common but since the end of the 1990s, a number of stock exchanges have merged following the trend toward demutualization of the stock exchanges - the process of converting exchanges from nonprofit, member-owned organizations to for-profit, investor-owned corporations - which started in the early 1990s (Aggarwal, 2002; Aggarwal \& Dahiya, 2006). This process of demutualization has made securities trading more competitive and it is believed that the prominent reasons of mergers are: economy of scale; economy of scope; increased revenue or market share; cross-selling; cost reduction including taxation; diversification; resource transfer; vertical integration; horizontal integration; employee or social capital acquisition; and absorption of similar businesses to reduce competition. These motivations all revolve around the realization of some synergy that would justify the merger/acquisition. (Philips, Faseruk \& Glew, 2014). When stock exchanges merge the benefits can be significant for the exchanges, the listed companies, and the investors (Kothari, 2008).

\subsection{Benefits to the Stock Exchange}

The exchanges, being merged have the opportunities to take advantage of the synergies that may be created. For instance, the transition by stock exchanges to electronic trading systems represents one of the greatest opportunities to reduce costs for individual exchanges and these savings are potentially greater when two exchanges merge (Philips et al., 2014). In this technology driven era there is a tendency to invest heavily in new technologies in order to be competitive. The stock exchanges around the world are also increasing their investments in new technologies that have the ability to satisfy the demands of sophisticated investors. The cost to implement such technologies into trading systems is very huge, but when stock exchanges merge their volume trade will increase substantially which will result in the reduction of the marginal cost per trade. An example of this type of savings was the streamlining of operations that occurred when the NYSE merged with Euronext in 2006. The total savings were reported to be $\$ 375$ million. This benefit was accomplished by integrating three cash trading systems and three derivatives systems into single global cash and derivatives platforms, and by reducing the 10 data centers to four and the four networks to one. (Aggarwal \& Dahiya, 2006). Moreover, advances in technology have allowed exchanges to reduce trading platform costs, to charge customers lower trading fees and to reach break-even earlier (Hasan, Malkamaki, \& Schmiedel, 2002, and Lee, 2002).

Economies of scale and scope have been described in the literature as one of the key determinants of stock exchange consolidations (Polato \& Floreani, 2009, and Chesini, 2007). The economies of scale are seen on both the demand and the supply side (Hasan \& Malkamaki, 2001). Supply side economies of scale relate to the typical structure of the stock exchange industry, with high fixed costs relating to information technology: where stock exchange consolidation results in the use of a single trading platform, average unit costs tend to decline as volumes grow (Paltrinieri, 2012). Thus, through mergers the exchanges have been able to fully exploit economies of scale, to deliver increased shareholder value and to reach leadership positions (Hasan, Schmiedel \& Song, 2010).

Pagano and Padilla (2005) studied the impact on trading fees and market liquidity of the merger between the Paris, Brussels, Amsterdam and Lisbon exchanges (Euronext), and their analysis of Euronext revealed that the trading volume increased by about 40 percentage and bid-ask spreads decreased by about 21 percentage, evidencing that liquidity increased and the trading fees decreased at the exchanges involved in the merger operations. 
The merger of exchanges brings in the opportunity of offering a greater number of financial instruments through one entity. Kokkoris and Olivares-Caminal (2007) argue that exchanges can direct their attention to offering a diverse set of products to customers through the combination of different functions, such as the offering of equities and derivatives. This is what happened in the case of the NYSE-Euronext merger, the NYSE was able to add a derivatives platform to its existing breadth of products, thereby improving its product mix.

\subsection{Benefits to the Listed Companies}

Chemmanur, He and Fulghieri (2008) outlined how the impact of a merger can be advantageous for listed companies. The first and foremost advantage is enhanced liquidity. Liquidity is the ability of the market to execute orders in a timely manner without having noteworthy impacts on prices (Kokkoris \& Olivares-Caminal, 2007).

Liquidity is important for firms aiming to control their cost of capital. Where the trading volumes are high, a particular stock becomes easier to sell with a reduced bid-ask spread. This also assists those investors who desire to sell their stock quickly and efficiently. In analyzing three U.S. regional exchange mergers, Nielsson (2009) shows that bid-ask spreads were reduced reflecting greater liquidity.

Liquidity increases with the number of potential investors. A deeper market may mitigate the impact of large, individual trades on future price movements. Enhanced liquidity reduces information and non-monetary transaction costs (i.e. cost reduction related to combining of trading systems). Direct costs can also be reduced which may entice investors to increase their trading activity (Nielsson, 2009). Thus, liquidity is improved as the market uncertainty is diminished, allowing investors to trade more actively. Companies always prefer to list their shares in an active market.

Nielsson (2009) further relates the impact of liquidity to various firm characteristics, such as foreign exposure, firm size and listing location. The primary measure of liquidity is turnover (the number of shares traded in a firm compared to the volume of outstanding shares). Nielsson states that for those firms which do not have visibility in foreign markets, turnover is relatively higher due to the likely reduction in transaction costs and a relatively higher degree of trading volume when compared to pre-merger activity.

\subsection{Benefits to the Investors}

For investors, the greatest benefit to having stock exchanges merge is the opportunity to trade different financial instruments in a technology friendly larger stock market with increased liquidity, transparent pricing and efficiency, at lower transaction costs.

Studies by Pagano and Padilla (2005) show that the merger of Paris and Amsterdam recorded significant decrease in trading fees and increase in trading volumes, highlighting the beneficial effects for investors/traders in terms of lower post-merger trading costs.

Investors also benefit from having a broader selection of financial instruments, allowing greater risk reduction through effective diversification (Kothari, 2008). Dealers/investors tend to trade on markets with a high number of dealers/investors to ensure greater market breadth and depth, a higher probability of closing deals, lower bid-ask spreads, and transaction costs. Dealers/investors tend to opt for markets with a high number of listed companies, to ensure greater portfolio diversification (Economides, 1993).

\subsection{Arab Stock Markets}

The developing country exchanges appear to favor internal made at home growth (Claessens, Djankov \& Klingebiel, 2000). The Arab emerging market exchanges have also pursued internal growth strategies rather than growth through cross-border consolidation (Kabir \& Jung, 2007). The main obstacle to consolidation in Arab countries, whether through internal growth or cross-border operations, is the weak, fragmented regulatory framework, together with macroeconomic instability and a lack of international institutional investors. This explains why most Arab exchanges are of limited size and liquidity (Paltrinieri, 2012).

Considering the limited size and population of the UAE, the existence of three stock exchanges may well limit each market in terms of liquidity, order flows from international institutional investors and new listing requests from local and regional firms. This situation mirrors that of the regional US exchanges in the 1960s, and is further complicated by the presence of more than one regulatory authority: ADX and DFM are regulated by Securities and Commodities Authority (SCA), while NASDAQ-Dubai is supervised by Dubai Financial Services Authority (Paltrinieri, 2012).

The common goal of Abu Dhabi and Dubai is to become the financial hub of the Persian Gulf and to set up a leading UAE stock exchange to act as a bridge between East and West, but the two emirates have pursued different strategies. ADX has opted for internal growth strategies and has marketed itself overseas to attract international investors, while 
DFM has sought to emulate the major international financial markets. In spite of all the efforts of both these stock markets their market capitalization and trading value are very low when compared to the major World Federation of Exchange (WFE) members (Paltrinieri, 2012). These literatures provoke the idea of the merger of ADX and DFM with the intent to benefit from the synergies of M\&A.

\section{Methodology}

The objective of this study is to probe into the benefits from having a larger stock market instead of the present two different markets: Abu Dhabi Securities Exchange in the emirates of Abu Dhabi and Dubai Financial Market in the emirates of Dubai. This study is solely based on secondary data collected from Abu Dhabi Stock Exchange (ADX), Dubai Financial Market (DFM), Emirates Securities and Commodities Authority (SCA), Bahrain Bourse (BHB), Qatar Stock Exchange (QSE), Kuwait Stock Exchange (KSE), Muscat Securities Market (MSM), Tadawul (Saudi Stock Exchange), Arab Monetary Fund (AMF) and various publications of the statistical departments, governments and the press. The study covers a period of five years from 2010 to 2014. The collected data are tabulated and analyzed using appropriate analytical tools.

\section{Analysis and Discussions}

To understand the benefits of the merger of Abu Dhabi Stock Exchange and Dubai Financial Market, first the data of all the exchanges in the GCC are compared and ranked on the basis of different parameters like trading, market capitalization, number of shares listed and number of days traded; then the data of ADX and DFM are combined into one exchange and is again ranked against the other exchanges in the GCC. The details of the analysis and related discussions are given below:

\subsection{Trading}

Any empirical analysis of trading activity in the stock market must start with a proper measure of price and volume.

4.1.1 Value of Stocks Traded

The size of the world stock market was estimated at about US\$64.19 trillion at the end of 2013. The total value of stocks traded in the GCC stock markets was US\$783 billion in 2014, more than half of this was in the Saudi Stock Exchange. For the purpose of the analysis, first the stock exchanges in the GCC were ranked on the basis of the value of stocks traded (Table 3), and the analysis clearly confirms the dominance of the Saudi Stock Exchange as it is ranked first, followed by Dubai Financial Market with second rank, whereas Abu Dhabi Securities Exchange is ranked far behind with rank five.

Table 3. Annual Value of Stocks Traded in the GCC Stock Markets (in Million U.S. \$)

\begin{tabular}{|c|c|c|c|c|c|c|c|}
\hline & 2010 & 2011 & 2012 & 2013 & 2014 & Average & Rank \\
\hline $\begin{array}{l}\text { Abu Dhabi Securities } \\
\text { Exchange }\end{array}$ & 9115.70 & 6644.59 & 6049.40 & 23092.59 & 39597.84 & 16900.02 & 5 \\
\hline Bahrain Bourse & 283.26 & 245.92 & 251.73 & 549.58 & 680.16 & 402.13 & 7 \\
\hline $\begin{array}{l}\text { Qatar Stock } \\
\text { Exchange }\end{array}$ & 17726.54 & 21589.79 & 17719.41 & 19883.61 & 52468.25 & 25877.52 & 3 \\
\hline $\begin{array}{l}\text { Dubai Financial } \\
\text { Market }\end{array}$ & 18473.25 & 8693.29 & 13245.55 & 43529.01 & 102614.06 & 37311.03 & 2 \\
\hline $\begin{array}{l}\text { Kuwait Stock } \\
\text { Exchange }\end{array}$ & 42772.42 & 20844.91 & 22997.87 & 40313.99 & 21051.83 & 25385.84 & 4 \\
\hline $\begin{array}{l}\text { Muscat Securities } \\
\text { Market }\end{array}$ & 3365.40 & 2535.17 & 2716.03 & 5770.28 & 5628.02 & 4002.98 & 6 \\
\hline $\begin{array}{l}\text { Saudi Stock } \\
\text { Exchange }\end{array}$ & 192445.39 & 286945.15 & 501417.19 & 361867.54 & 561198.23 & 380774.70 & 1 \\
\hline Total & 284181.96 & 347498.82 & 564397.18 & 495006.60 & 783238.39 & 494864.59 & \\
\hline
\end{tabular}

Sources: Compiled from AMF, ADX; BHB; QSE; DFM; KSE; MSM and Tadawul.

The stock exchanges were once more ranked after combining Abu Dhabi Securities Exchange and Dubai Financial Market (Table 4), and even after this the Saudi Stock Exchange continues at the top slot affirming its unconquerable position in the GCC. The Combined ADX \& DFM gets the second rank. The analysis shows that the Abu Dhabi Securities Exchange will be the beneficiary of this proposed merger as its position improves from the fifth to the second. 
Table 4. Annual Value of Stocks Traded in the GCC Stock Markets (in Million U.S. \$)

\begin{tabular}{lrrrrrrr}
\hline & \multicolumn{1}{c}{2010} & \multicolumn{1}{c}{2011} & \multicolumn{1}{c}{2012} & \multicolumn{1}{c}{2013} & \multicolumn{1}{c}{2014} & Average & Rank \\
\hline Bahrain Bourse & 283.26 & 245.92 & 251.73 & 549.58 & 680.16 & 402.13 & 6 \\
Qatar Stock Exchange & 17726.54 & 21589.79 & 17719.41 & 19883.61 & 52468.25 & 25877.52 & 3 \\
Kuwait Stock Exchange & 42772.42 & 20844.91 & 22997.87 & 40313.99 & 21051.83 & 29596.20 & 4 \\
Muscat Securities Market & 3365.40 & 2535.17 & 2716.03 & 5770.28 & 5628.02 & 4002.98 & 5 \\
Saudi Stock Exchange & 192445.39 & 286945.15 & 501417.19 & 361867.54 & 561198.23 & 380774.70 & 1 \\
Combined ADX \& DFM & 27588.95 & 15337.88 & 19294.95 & 66621.60 & 142211.90 & 54211.06 & 2 \\
Total & 284181.96 & 347498.82 & 564397.18 & 495006.60 & 783238.39 & 494864.59 & \\
\hline
\end{tabular}

Sources: Compiled from AMF, ADX; BHB; QSE; DFM; KSE; MSM and Tadawul.

\subsubsection{Volume of Stocks Traded}

Trading volume is the number of shares or contracts that indicates the overall activity of a security or market for a given period. Trading volume is an important technical indicator an investor uses to confirm a trend or trend reversal. The total number of all shares that changed hands in a stock exchange such as Dubai Financial Market is the total market volume. The total volume of shares traded in the GCC stock exchanges in 2014 was 352 billion. The average total volume of shares traded during the period of study is observed to be the highest in the Dubai Financial Market, closely followed by Saudi Stock Exchange and Abu Dhabi Securities Exchange is ranked fourth (Table 5).

Table 5. Annual Volume of Share Traded in the GCC Stock Markets (in Million)

\begin{tabular}{|c|c|c|c|c|c|c|c|}
\hline & 2010 & 2011 & 2012 & 2013 & 2014 & Average & Rank \\
\hline $\begin{array}{l}\text { Abu Dhabi Securities } \\
\text { Exchange }\end{array}$ & 17111.97 & 15601.53 & 16343.68 & 51455.36 & 58522.27 & 31806.96 & 4 \\
\hline Bahrain Bourse & 610.12 & 486.57 & 561.14 & 1791.67 & 1096.87 & 909.27 & 7 \\
\hline Qatar Stock Exchange & 2012.25 & 2162.66 & 2190.22 & 1848.73 & 4248.49 & 2492.47 & 6 \\
\hline Dubai Financial Market & 37578.17 & 25018.05 & 40462.90 & 127180.36 & 158898.20 & 77827.54 & 1 \\
\hline Kuwait Stock Exchange & 73682.50 & 37877.47 & 27195.08 & 129921.34 & 54659.79 & 64667.24 & 3 \\
\hline $\begin{array}{l}\text { Muscat Securities } \\
\text { Market }\end{array}$ & 2990.60 & 2341.97 & 4247.54 & 8033.08 & 6411.16 & 4804.87 & 5 \\
\hline Saudi Stock Exchange & 31555.34 & 47640.18 & 83653.14 & 51916.56 & 68420.65 & 56637.17 & 2 \\
\hline Total & 165540.95 & 131128.43 & 174653.7 & 372147.10 & 352257.43 & 239145.52 & \\
\hline
\end{tabular}

Sources: Compiled from AMF, ADX; BHB; QSE; DFM; KSE; MSM and Tadawul.

The stock exchanges were once more ranked after merging Abu Dhabi Securities Exchange and Dubai Financial Market (Table 6), and it is seen that the combined ADX \& DFM leads the ranking with the first position. The average annual volume of the combined exchange is 109,634.50 million whereas the second ranked Saudi Stock Exchange is far behind with an average annual volume of only $56,637.17$ million, which is just slightly above $50 \%$ of that of the combined ADX \& DFM. This clearly restates the benefits of the proposed merger. This is an opportunity to become the largest stock exchange in the GCC on the basis of volume of shares traded and reap the advantage of economies of scale and visibility, in fact the authorities should speed up the merger process so that all stakeholders benefit at the earliest.

Table 6. Annual Volume of Share Traded in the GCC Stock Markets (in Million)

\begin{tabular}{lrrrrrrr}
\hline & \multicolumn{1}{c}{2010} & \multicolumn{1}{c}{2011} & \multicolumn{1}{c}{2012} & \multicolumn{1}{c}{2013} & 2014 & Average & Rank \\
\hline Bahrain Bourse & 610.12 & 486.57 & 561.14 & 1791.67 & 1096.87 & 909.27 & 6 \\
Qatar Stock Exchange & 2012.25 & 2162.66 & 2190.22 & 1848.73 & 4248.49 & 2492.47 & 5 \\
Kuwait Stock Exchange & 73682.50 & 37877.47 & 27195.08 & 129921.34 & 54659.79 & 64667.24 & 3 \\
Muscat Securities Market & 2990.60 & 2341.97 & 4247.54 & 8033.08 & 6411.16 & 4804.87 & 4 \\
Saudi Stock Exchange & 31555.34 & 47640.18 & 83653.14 & 51916.56 & 68420.65 & 56637.17 & 2 \\
Combined ADX \& DFM & 54690.14 & 40619.58 & 56806.58 & 178635.72 & 217420.47 & 109634.50 & 1 \\
Total & 165540.95 & 131128.43 & 174653.70 & 372147.10 & 352257.43 & 239145.52 &
\end{tabular}

Sources: Compiled from AMF, ADX; BHB; QSE; DFM; KSE; MSM and Tadawul. 


\subsection{Number of Transaction}

In an active stock market the number of transaction carried out would be more and large number of investors and dealers are attracted towards this market as it would be more liquid, ensures greater market breadth and depth, lower bid-ask spreads, and lower transaction costs. Analysis made on the basis of number of transactions executed year on year keeps Saudi Stock Exchange at the top with an annual average of 12,213,644 transactions, followed by Qatar Stock Exchange with an annual average of 1,144,464 transactions, Dubai Financial Market and Abu Dhabi Securities Exchange, are ranked fourth and fifth respectively (Table 7).

Table 7. Annual Number of Transactions in the GCC Stock Markets

\begin{tabular}{|c|c|c|c|c|c|c|c|}
\hline & 2010 & 2011 & 2012 & 2013 & 2014 & Average & Rank \\
\hline $\begin{array}{l}\text { Abu Dhabi Securities } \\
\text { Exchange }\end{array}$ & 352879 & 278474 & 257719 & 555046 & 863908 & 461605 & 5 \\
\hline Bahrain Bourse & 19375 & 9940 & 8612 & 12861 & 13570 & 12872 & 7 \\
\hline Qatar Stock Exchange & 1017570 & 1045587 & 769263 & 915347 & 1974551 & 1144464 & 2 \\
\hline Dubai Financial Market & 777326 & 442069 & 621421 & 1337857 & 2388581 & 1113451 & 4 \\
\hline Kuwait Stock Exchange & 1237908 & 608585 & 319669 & 2252744 & 1226739 & 1129129 & 3 \\
\hline Muscat Securities Market & 536135 & 353121 & 322074 & 449807 & 398104 & 411848 & 6 \\
\hline Saudi Stock Exchange & 16108992 & 11296213 & 10764105 & 11770244 & 11128667 & 12213644 & 1 \\
\hline Total & 20050185 & 14033989 & 13062863 & 17293906 & 17994120 & 16487013 & \\
\hline
\end{tabular}

Sources: Compiled from AMF, ADX; BHB; QSE; DFM; KSE; MSM and Tadawul.

A further ranking is made in in Table 8 after combining the ADX and DFM. It is observed from Table 8 that the position of the combined stock exchange improved to rank two, the second best in the GCC, whereas before the merger both the stock exchanges were almost at the bottom of the ranking table. Thus this parameter encourages the merger of the two exchanges.

Table 8. Annual Number of Transactions in the GCC Stock Markets

\begin{tabular}{lrrrrrrr}
\hline & \multicolumn{1}{c}{2010} & \multicolumn{1}{c}{2011} & \multicolumn{1}{c}{2012} & \multicolumn{1}{c}{2013} & \multicolumn{1}{c}{2014} & Average & Rank \\
\hline Bahrain Bourse & 19375 & 9940 & 8612 & 12861 & 13570 & 12872 & 6 \\
Qatar Stock Exchange & 1017570 & 1045587 & 769263 & 915347 & 1974551 & 1144464 & 3 \\
$\begin{array}{l}\text { Kuwait Stock } \\
\text { Exchange }\end{array}$ & 1237908 & 608585 & 319669 & 2252744 & 1226739 & 1129129 & 4 \\
$\begin{array}{l}\text { Muscat Securities } \\
\text { Market }\end{array}$ & 536135 & 353121 & 322074 & 449807 & 398104 & 411848 & 5 \\
$\begin{array}{l}\text { Saudi Stock Exchange } \\
\text { Combined ADX \& }\end{array}$ & 16108992 & 11296213 & 10764105 & 11770244 & 11128667 & 12213644 & 1 \\
$\begin{array}{l}\text { DFM } \\
\text { Total }\end{array}$ & 1130205 & 720543 & 879140 & 1892903 & 3252489 & 1575056 & 2 \\
\hline
\end{tabular}

Sources: Compiled from AMF, ADX; BHB; QSE; DFM; KSE; MSM and Tadawul.

\subsection{Market Capitalization}

The Stock Market Capitalization of a country is the aggregated market value equity of companies in the respective equity market and has traditionally been used as a measure of stock market activity (Rajan \& Zingales, 1998; Torre, Gozzi \& Schmukler, 2006). It is also used to reflect a country's level of credit and economic growth, in anticipation of future growth in the equity market. Stock Market Capitalization also influences economic growth predictions and public consensus concerning the value of the stock market. The total market capitalization of the GCC stock markets in 2014 was estimated to be US\$1,053,238.14 million. Among them Saudi Stock Exchange had the highest market capitalization with an annual average of US $\$ 403,862.52$ million during the period of study, followed by Qatar Stock Exchange with an annual average of US\$144,175.38 million. Abu Dhabi Securities Exchange and Dubai Financial Market are ranked fourth and fifth respectively (Table 9). 
Table 9. Market Capitalization (in Million U.S. \$)

\begin{tabular}{lrrrrrrr}
\hline & \multicolumn{1}{c}{2010} & \multicolumn{1}{c}{2011} & \multicolumn{1}{c}{2012} & \multicolumn{1}{c}{2013} & 2014 & Average & Rank \\
\hline Abu Dhabi Securities & 71268.62 & 71059.08 & 76568.42 & 116909.90 & 133964.72 & 93954.15 & 4 \\
Exchange & & & & & & & \\
Bahrain Bourse & 19902.66 & 16513.32 & 15423.58 & 18466.25 & 21058.17 & 18272.80 & 7 \\
Qatar Stock Exchange & 123316.64 & 128439.21 & 130677.09 & 152588.80 & 185855.18 & 144175.38 & 2 \\
Dubai Financial Market & 54722.23 & 49548.92 & 50050.85 & 70713.08 & 87863.73 & 62579.76 & 5 \\
Kuwait Stock Exchange & 124919.97 & 100927.95 & 104210.28 & 110275.46 & 102923.48 & 108651.43 & 3 \\
Muscat Securities Market & 21712.05 & 19697.72 & 22265.96 & 27407.95 & 27327.52 & 23682.24 & 6 \\
Saudi Stock Exchange & 353419.01 & 338791.41 & 373404.62 & 459452.22 & 494245.34 & 403862.52 & 1 \\
Total & 769261.18 & 724977.61 & 772600.80 & 955813.66 & 1053238.14 & 855178.28 & \\
\hline Sourcs: Compi
\end{tabular}

Sources: Compiled from AMF, ADX; BHB; QSE; DFM; KSE; MSM and Tadawul.

When the raking is done after the combination of ADX and DFM, Saudi Stock Exchange continues to be on the top, but the combined ADX and DFM gets the second rank which highly favors the merger of the two for growth and development (Table 10).

Table 10. Market Capitalization (in Million U.S. \$)

\begin{tabular}{lrrrrrrc}
\hline & \multicolumn{1}{c}{2010} & \multicolumn{1}{c}{2011} & \multicolumn{1}{c}{2012} & \multicolumn{1}{c}{2013} & \multicolumn{1}{c}{2014} & \multicolumn{1}{c}{ Average } & Rank \\
\hline Bahrain Bourse & 19902.66 & 16513.32 & 15423.58 & 18466.25 & 21058.17 & 18272.80 & 6 \\
Qatar Stock Exchange & 123316.64 & 128439.21 & 130677.09 & 152588.80 & 185855.18 & 144175.38 & 3 \\
Kuwait Stock & 124919.97 & 100927.95 & 104210.28 & 110275.46 & 102923.48 & 108651.43 & 4 \\
$\begin{array}{l}\text { Exchange } \\
\text { Muscat Securities }\end{array}$ & 21712.05 & 19697.72 & 22265.96 & 27407.95 & 27327.52 & 23682.24 & 5 \\
$\begin{array}{l}\text { Market } \\
\text { Saudi Stock Exchange }\end{array}$ & 353419.01 & 338791.41 & 373404.62 & 459452.22 & 494245.34 & 403862.52 & 1 \\
Combined ADX \& & 125990.85 & 120608.00 & 126619.27 & 187622.98 & 221828.45 & 156533.91 & 2 \\
DFM & 769261.18 & 724977.61 & 772600.80 & 955813.66 & 1053238.14 & 855178.28 & \\
Total &
\end{tabular}

Sources: Compiled from AMF, ADX; BHB; QSE; DFM; KSE; MSM and Tadawul.

\subsection{Number of Shares Listed}

Companies have an inclination to list on exchanges with a high number of listed companies as they will get benefits of higher visibility, greater liquidity and reduced cost. Similarly investors/ dealers tend to opt for stock exchanges with a high number of listed companies as it enables greater risk reduction through effective diversification. Kuwait Stock Exchange has the highest number of shares listed as at the end of May, 2015 with 205 shares, followed by Saudi Stock Exchange with 170 shares and the position of Dubai Financial Market and Abu Dhabi Securities Exchange are four and five with 71 and 70 shares respectively (Table 2). Whereas when the raking is done after the combination of ADX and DFM its position improves to third position with 141 shares just behind Kuwait Stock Exchange and Saudi Stock Exchange. Moreover, the merger of exchanges will brings in the opportunity of offering a greater number of financial instruments through one entity, which is currently offered through two different exchanges the ADX and DFM.

\subsection{Number of Days Traded}

The average annual number of trading days is varying from 249 to 234 days during the period of study. Dubai Financial Market ranks top with 249 days and Abu Dhabi Securities Exchange ranks second. Hence after the merger also the combined ADX and DFM will continue to lead the table as far as the number of days traded are concerned (Table 11). 
Table 11. Number of Days Traded every year

\begin{tabular}{lccccccc}
\hline & 2010 & 2011 & 2012 & 2013 & 2014 & Average & Rank \\
\hline Abu Dhabi Securities & 244 & 245 & 250 & 248 & 251 & 248 & 2 \\
Exchange & 246 & 245 & 247 & 246 & 245 & 246 & 3 \\
Bahrain Bourse & 244 & 233 & 224 & 232 & 236 & 234 & 7 \\
Qatar Stock Exchange & 247 & 250 & 252 & 249 & 249 & 249 & 1 \\
Dubai Financial Market & 242 & 243 & 250 & 247 & 244 & 245 & 4 \\
Kuwait Stock Exchange & 245 & 242 & 243 & 242 & 237 & 242 & 6 \\
Muscat Securities Market & 238 & 243 & 244 & 245 & 245 & 243 & 5 \\
Saudi Stock Exchange & 245 &
\end{tabular}

Sources: Compiled from AMF, ADX; BHB; QSE; DFM; KSE; MSM and Tadawul.

\section{Conclusions, Limitations, and Directions for Future Research}

This study shows that the merger of ADX and DFM will bring in benefits to all the stakeholders by reducing costs of operations facilitated by the large scale operations, sophisticated technology, single trading platform, one investor number or identity and lower trading cost. On all parameters of the study it is seen the merger benefits ADX and DFM. The analysis based on the value stock traded the position of ADX improves to rank two from the present fifth rank; on the volume of stock traded the position of ADX improves to rank one from the present fourth position; on the number of transaction the rank of the merged exchange improves to rank two from the present position of fourth rank for DFM and fifth rank for ADX; on the market capitalization the position of the merged exchange improves to rank two from the existing fourth position for ADX and fifth for DFM; on the number of shares listed the position of the merged exchange improves to third from the present fourth position for DFM and fifth for ADX and on the basis of number of days traded DFM and ADX are currently having the first two positions, after the merger also they can continue in the top position.

Likewise, the merger will offer more conveniences to the investors as they will have a wider choice of securities and will be able to trade on all these scripts from a single platform with a sing investor number. Consolidation of IT and back office operations can save on the cost of operations and as the scale of operation increases they can have modern sophisticated technology and professional personnel in the office, which in turn will enhance the efficiency of the organization and further reduce the operations costs. This will allow exchanges to charge customers lower trading fees and reach break-even earlier. Merger will enhance the attractiveness of the stock market for listing. Companies prefer to list on exchanges with a high number of listed companies because they will have greater liquidity as there is the presence of high number of investors which can result in reducing the cost of capital for the listing company. Thus through the merger of ADX and DFM UAE will be able to attract more local and regional companies which will enhance revenue, profitability and presence in the region. This will be a right step in the march of becoming the financial hub of the region.

This study has limitations of its own as it is confined to the positive side of the merger. There is scope to do further research on areas like: the disadvantages of the proposed merger; the factors hindering the merger exercise, the political will for this exercise and so on.

\section{References}

Aggarwal, R. (2002). Demutualization and corporate governance of stock exchanges. Journal of Applied Corporate Finance, 15(1), 105-113. http://dx.doi.org/10.1111/j.1745-6622.2002.tb00345.x

Aggarwal, R. \& Dahiya, S. (2006). Demutualization and Public Offerings of Financial Exchanges. Journal of Applied Corporate Finance, 18(3), 96-106. http://dx.doi.org/10.1111/j.1745-6622.2006.00102.x

Chemmanur, T. J., He, J. \& Fulghieri, P. (2008). Competition and Cooperation among Exchanges: Effects on Corporate Cross-Listing Decisions and Listing Standards. Journal of Applied Corporate Finance, 20(3), 76-90. http://dx.doi.org/10.1111/j.1745-6622.2008.00195.x

Chesini G. (2007). From demutualisation to globalisation: new challenges for Stock Exchanges. International Review of Business Research Paper.

Claessens S., Djankov S., Klingebiel D. (2000). Stock Markets in Transition Economies. Working paper, Financial Sector Discussion Paper No.5, The World Bank. http://dx.doi.org/10.2139/ssrn.240703 
Economides N. (1993). Network economics with application to finance. Financial Markets, Institutions and Instruments, (5).

Hammoudeh, Shawkat \& Aleisa Eisa (2004). Dynamic Relationships among GCC Stock Markets and Nymex Oil Futures. Contemporary Economic Policy, Western Economic Association International. http://dx.doi.org/10.1093/cep/byh018

Hasan I., Malkamaki M. (2001). Are expansions cost effective for stock exchanges? A global perspective. Journal of Banking and Finance, (25). http://dx.doi.org/10.1016/S0378-4266(01)00194-7

Hasan, I., Malkamaki, M. \& Schmiedel, H. (2002). Technology, automation, and productivity of stock exchanges: international evidence. Discussion Paper No. 4, Bank of Finland, Helsinki, February 27.

Hasan I., Schmiedel H., Song L. (2010). Growth strategies and value creation: what work best for stock exchanges? working paper, Bank of Finland Research Discussion Papers, No.2.

Kabir Hassan M., Jung Suk-Yu (2007). Stock Exchange Alliances in Organization of Islamic Conference Countries, working paper, Networks Financial Institute, No.18.

Kokkoris, I. \& Olivares-Caminal, R. (2007). Some issues on cross-border stock exchange mergers. University of Pennsylvania Journal of International Law, 29(2), 455-526.

Kothari, L. K. (2008). Global Regulation for Global Stock Exchanges: The NYSE-Euronext Merger. Temple International and Comparative Law Journal, 22(2), 499-521.

Lee R. (2002). The future of securities exchanges, The Wharton Financial institution center, University of Pennsylvania.

Nielsson, U. (2009). Stock Exchange Merger and Liquidity. Journal of Financial Markets, 12(2), 229-267. http://dx.doi.org/10.1016/j.finmar.2008.07.002

Pagano M., Padilla J. (2005). Gains from stock exchange integration: the Euronext evidence, working paper, Mimeo.

Paltrinieri, Andrea, (2012). Stock Exchange Mergers in the Emerging Markets: A Case Study of the United Arab Emirates. http://dx.doi.org/10.2139/ssrn.2156090

Patrick Philips, Alex Faseruk \& Ian Glew (2014). An Anatomy of Stock Exchange Mergers with a Case Study of the LSE-TMX Merger. Journal of Accounting and Finance, 14(2).

Polato M., Floreani J. (2009). "Strategie competitive e creazione di valore nell'exchange industry: profili regolamentari e di governance" in Brogi M., Banca, Mercati e Risparmio, Saggi in onore di Tancredi Bianchi, 3, Bancaria editrice.

Rajan, R. G. \& Zingales, L. (1998). Financial dependence and growth. American Economic Review, 88, 559-86.

Torre, A., Gozzi, J. C. \& Schmukler, S. L. (2006). Stock market development under globalization: whither the gains from reforms? Journal of Banking and Finance, 31, 1731-54. http://dx.doi.org/10.1016/j.jbankfin.2006.11.008

Abu Dhabi Securities Exchange. (various years). “ADX Annual Report”, available at http://www.adx.ae.

Arab Monetary Fund. (various years). "Arab Capital, Yearly Performance”, available at http://www.amf.org.ae

Bahrain Bourse. (various years). "Annual Report” available at http://www.bahrainbourse.net/bhb

Dubai Financial Markets. (various years). "DFM Annual Report" available at http://www.dfm.ae

Kuwait Stock Exchange. (various years). "Annual Report" available at http://www.kse.com.kw

Muscat Securities Market. (various years). “Annual Report” available at https://www.msm.gov.om

NASDAQ Dubai available at http://www.nasdaqdubai.com

Qatar Stock Exchange. (various years). "Annual Report” available at http://www.qe.com.qa

Saudi Stock Exchange (various years), "Annual Report" available at http://www.tadawul.com.sa

United Arab Emirates. 'Economic Overview' available at http://www.gulfbase.com

WFE 2013 Market Highlights. (2013). available at http://www.worldexchanges.org/files/2013_WFE_Market_Highlights.pdf, dated (28 January 2014)

World Federation of Exchange. (various years from 2008 to 2012). "Cost and Revenue Survey", available at $\mathrm{http}: / /$ www.world-exchanges.org. 